\title{
Copepod feeding study in the upper layer of the tropical South China Sea
}

\author{
Li-Chun Tseng • Hans-Uwe Dahms • \\ Qing-Chao Chen $\cdot$ Jiang-Shiou Hwang
}

Received: 26 October 2008/Revised: 30 April 2009/ Accepted: 11 May 2009/Published online: 30 May 2009

(C) Springer-Verlag and AWI 2009

\begin{abstract}
The South China Sea (SCS) is the world's largest marginal sea being notable for vertical mixing at various scales resulting in a sequence of chemical and biological dynamics in surface waters. We investigated the ingestion, gut content, evacuation and clearance rates of copepods collected from six stations (including a South East Asia Time Series station) along a transect line in the tropical of a SCS cruise during September 27, 1999 to October 2, 1999. The goal of the present study was to understand the feeding ecology of copepods in the upper water layers $(0-5 \mathrm{~m})$ of the northern SCS during autumn. We measured the gut pigment contents of 33 copepod species by the gut fluorescence method. The gut chlorophyll $a$ values of most small size copepods $(<1 \mathrm{~mm})$ were lower than $1.00 \mathrm{ng} \mathrm{Chl} a$ individual $^{-1}$. The highest gut pigment content was recorded in Scolecithrix danae ( $7.07 \mathrm{ng} \mathrm{Chl} a$ individual $^{-1}$ ). The gut pigment contents of 33 copepod species (including 70 samples and 1,290 individuals) estimated is negatively correlated with seawater temperature (Pearson correlation $r=-0.292$, $P=0.014)$ and is positively correlated with the chlorophyll $a$ concentration of ambient waters (Pearson correlation $r=0.243, P=0.043$ ). Mean gut pigment content, ingestion and clearance rates (from 80 samples and 1,468 individuals) show that larger copepods $(>2 \mathrm{~mm})$ had
\end{abstract}

Communicated by H.-D. Franke.

L.-C. Tseng · H.-U. Dahms · J.-S. Hwang ( $₫)$

Institute of Marine Biology, National Taiwan Ocean University,

2 Peining Road, Keelung 20224, Taiwan, ROC

e-mail: jshwang@mail.ntou.edu.tw

Q.-C. Chen

South China Sea Institute of Oceanology,

Chinese Academy of Science, Guangzhou, China significantly higher values than medium sized copepods (1-2 mm) and smaller sized copepods. The present study shows that the performance of feeding on phytoplankton was variable in different sized copepod groups, suggesting that copepods obtained in the tropical area of the southeastern Taiwan Strait might be opportunistic feeders.

Keywords Copepod · Gut content · Feeding ·

Evacuation rate $\cdot$ Ingestion rate $\cdot$ South China Sea

\section{Introduction}

Planktonic copepods are key organisms in aquatic ecosystems, because they are the most important link between the primary productivity of microalgae and the production of many fish species in the oceans (Irigoien et al. 2002; Tseng et al. 2008a). This has a qualitative and a quantitative dimension. Qualitative and quantitative aspects of copepod feeding are influenced by several parameters, which include copepod abundance (Atkinson 1996), body length (Morales et al. 1991), time of the day (Saito and Taguchi 1996), seasonal variance (Razouls et al. 1998; Tseng et al. 2008b), type of food (Stoecker and Capuzzo 1990; Atkinson 1996), quantity of food (Ellis and Small 1989) and physical parameters such as seawater temperature (Dam and Peterson 1988). Copepod feeding is dynamic and may have a wide variation (Hwang et al. 1998; Lee 1999; Tseng et al. 2008c).

One of the critical relationships involved in the dynamics of pelagic ecosystems is the trophic relationship between producers (phytoplankton) and consumers (like zooplankton). The quantification of phytoplankton utilization by grazing allows to calculate the downward transport of organic matter. Phytoplankter are the primary processors 
of photoautotrophically synthesized organic matter in the oceans, and zooplankton plays major roles in the nutrient transfer to higher trophic levels. By their grazing vertically migrating or decaying zooplankton also transport a substantial amount of nutrients and carbon from surface waters to deeper water layers. Aquatic zooplankton has a great impact on the transfer of energy and nutrients throughout the food web, as it links primary production with higher trophic levels (Turner 2004). However, different zooplankton taxa play different roles with different impact. Copepods are probably the most abundant metazoans in the ocean (Schminke 2007) and constitute $>90 \%$ of the total zooplankton abundance in the Taiwan Strait (Lo et al. 2004), in the northeastern South China Sea (SCS) (Tseng et al. 2008a) and other parts of the world's oceans (Froneman et al. 2000).

Feeding diets may shift among individuals of a particular species, with age (considering particularly ontogenetic changes) (Meyer et al. 2002), and with gender (Dahms and Qian 2006). There might be seasonal shifts that also reflect community shifts of available food sources. Feeding strategies might be selective (Go et al. 1998) or nonselective (Tseng et al. 2008c). The taxonomic and biochemical complexity of the trophic oceanic environment makes it difficult to apply these concepts to copepod feeding (Kleppel 1992). There are attempts to trace copepod diets by the study of their feeding behavior (Tackx et al. 2003), the direct examination of diets in their gut (Nishida and Ohtsuka 1996; Wu et al. 2004), or the examination of their fecal pellets (Turner et al. 2001). However, gut and fecal pellet studies seem not to be a reliable way to determine the composition of copepod food since digestion can be very rapid and many food sources have no skeletal remains that could be retrieved. Bottle incubations in situ have traditionally been used to characterize diets of calanoid copepods and to quantify temporal ratios of consumption (Kleppel et al. 1996).

Quantifying rates of phytoplankton utilization by copepods is a necessary step to understand the mechanisms that regulate phytoplankton populations in marine ecosystems and the flux of organic matter. Copepod feeding processes cannot easily be generalized, as copepods exhibit herbivorous, omnivorous, carnivorous and detritivorous feeding habits (Schultes et al. 2006; Dahms and Qian 2005). Copepod feeding also have impacts on microbial assemblages (Schnetzer and Caron 2005), so in their consumption of bacterial production (Bouvy et al. 2006). The reproductive activity and physiological status of copepods are strikingly affected by their diets (Ceballos and AlvarezMarques 2006; Dahms et al. 2006). Copepods are selective in their feeding process (Meyer-Harms and von Bodungen 1997). The selectivity is sensitive and copepods can distinguish between food particles of different nutritional status (Cotonnec et al. 2001), algal composition (Atkinson 1994; Wyckmans et al. 2007), concentration (Katechakis and Stibor 2004), taste (DeMott and Tessier 2002) and toxicity of algae (DeMott and Tessier 2002). The relationship between primary production, grazing and the export of organic material is strongly determined by the size structure of the trophic pathways (Morales et al. 1990; Froneman et al. 2000).

Large filter feeders are able to feed on a wider size spectrum of algae than are small filter feeders (Hansen et al. 1997). The relationship between primary production, grazing and export of materials is among other variables related to the size structure of the members of the trophic web (Froneman et al. 2000). The size structures of zooplankton assemblages may affect phytoplankton communities differentially. A study of Møller (2005) reviewed and suggests that the size ratios of copepod-to-prey is $<55$. His results showed that the grazing pressure performance was the interaction of size composition in both zooplankton and phytoplankton communities.

Copepods may intensify and accelerate the downward flux of organic matter as they produce larger fecal pellets, which have relatively higher sinking rates and carbon values than other zooplankter (Froneman et al. 2000; Turner 2002). Hence, information of phytoplankton utilization by copepods is a necessary step for the understanding of the mechanisms that regulate phytoplankton populations in marine ecosystems and the downward transport of organic matter. Size effects, together with spatial and temporal heterogeneities of copepod feeding on phytoplankton have been of major concern in a number of previous studies (Hansen et al. 1997; Romam and Gauzens 1997; Gowen et al. 1999; Head et al. 1999).

There are several studies of copepod feeding in the western Pacific Ocean with examples from the East China Sea (Wang and Fan 1997), northern Taiwan (Hwang et al. 1998; Wong et al. 1998), southwestern Taiwan Strait (Tseng et al. 2008c) and Hong Kong Harbor (Tan et al. 2004). So far, information on copepod feeding on phytoplankton from the SCS has not been studied as yet. The present study is the first in situ copepod feeding study in the region of the northern SCS. The aim of the present study is to reveal the gut chlorophyll $a$ content, evacuation and ingestion rates of dominant copepods and compare the feeding results of different body size groups in the northern SCS.

\section{Material and methods}

\section{Zooplankton sampling}

For the present study zooplankton was collected in the northern SCS during cruise 563 of Ocean Research Vessel 


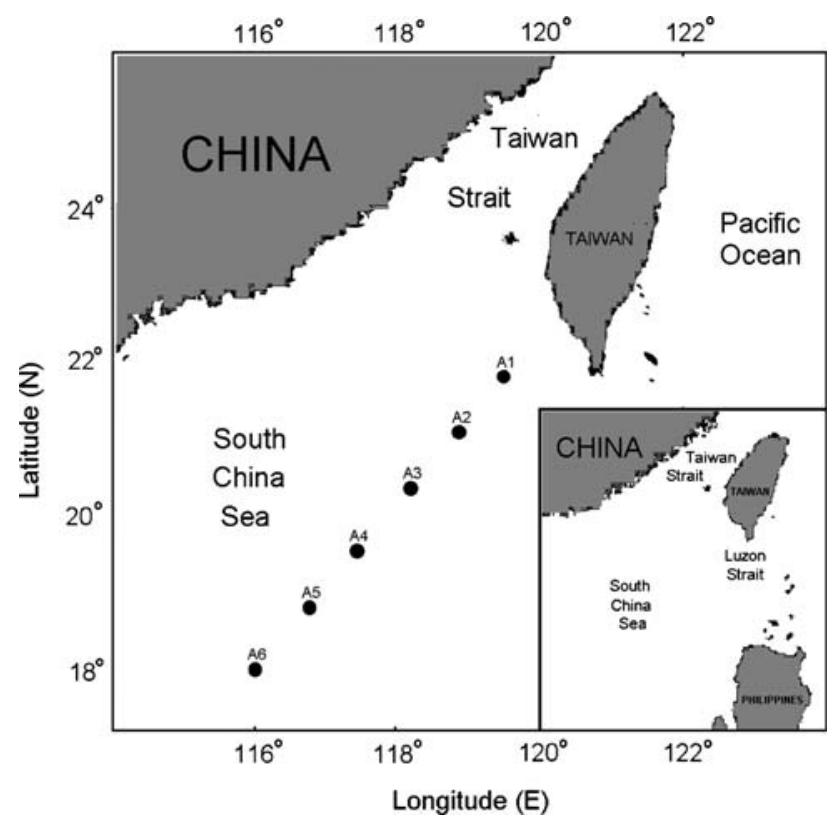

Fig. 1 Map of the sampling stations of Ocean Research Vessel III cruise 563, from September 27 to October 2, 1999. Station A6 is the South-East Asia Time Series station (SEATS) in the South China Sea

Table 1 Location and sampling time of each sampling station of cruise 563 in the northern South China Sea

\begin{tabular}{llll}
\hline Station & \multicolumn{2}{l}{ Location of station } & \multirow{2}{*}{ Sampling date, time } \\
\cline { 2 - 3 } & Longitude (E) & Latitude (N) & \\
\hline A1 & $119^{\circ} 30.043^{\prime \prime}$ & $21^{\circ} 50.076^{\prime \prime}$ & 27 Sep, 16:40 \\
A2 & $118^{\circ} 52.544^{\prime \prime}$ & $21^{\circ} 07.045^{\prime \prime}$ & 27 Sep, 23:45 \\
A3 & $118^{\circ} 11.031^{\prime \prime}$ & $20^{\circ} 20.167^{\prime \prime}$ & 28 Sep, 06:50 \\
A4 & $117^{\circ} 27.700^{\prime \prime}$ & $19^{\circ} 35.150^{\prime \prime}$ & 28 Sep, 14:00 \\
A5 & $116^{\circ} 47.860^{\prime \prime}$ & $18^{\circ} 49.913^{\prime \prime}$ & 28 Sep, 20:00 \\
A6 & $115^{\circ} 28.558^{\prime \prime}$ & $18^{\circ} 00.957^{\prime \prime}$ & 29 Sep, 03:25 \\
\hline
\end{tabular}

Station A6 is the SEATS station

III from September 27 to October 2, 1999. The details and locations of sampling stations are shown in Fig. 1 and Table 1. A transect line with six stations was chosen southwest of Taiwan north to the southernmost of the South East Asia Time Series (SEATS) station. The southernmost station (A6) is the SEATS station. Zooplankton samples were collected from the upper $5 \mathrm{~m}$ of each station by horizontal tows using $100 \mu \mathrm{m}$ mesh nets. The conductivity, temperature and depth (CTD) instrument was used on board to obtain the relevant physical information of temperature and salinity before zooplankton tows were taken. The volume of water filtered through the net was estimated from the readings of flow meters mounted in the center of the net opening. After retrieval, the content of the first tow was immediately preserved in seawater of a $5 \%$ formalin solution, for subsequent copepod identification and enumeration. The content of a second tow was stored in a plastic bag and was immediately frozen with liquid nitrogen. Then, samples were stored at $-20^{\circ} \mathrm{C}$ in the dark until gut pigment analysis was done. Water samples for chlorophyll $a$ analysis (Strickland and Parsons 1972) were collected from 1 to $2 \mathrm{~m}$ below the surface.

Copepod size fraction, identification and enumeration

In the laboratory, samples were repeatedly split with a Folsom splitter until the sub-sample contained about 300-500 individuals then used to taxonomic identification and enumeration. The sub-samples were moved to a scaled glass dish for the estimation of body length and then fractionated in three size categories [large $(>2 \mathrm{~mm})$, medium $(1-2 \mathrm{~mm})$, small $(<1 \mathrm{~mm})]$ using a dissecting microscope. Species composition and abundances were determined by counting the adults. Particular references for identification were Chen and Zhang (1965), Chen et al. (1974) and Zheng et al. (1982). Only adults of dominant copepod species were chosen for gut pigment measures which are known from the literature as 'potentially herbivorous' and phytoplankton consumers.

\section{Chlorophyll $a$ extraction}

Chlorophyll $a$ levels in the seawater were measured as described in Parsons et al. (1984) as they were widely used in feeding studies around Taiwan (Hwang et al. 1998; Wong et al. 1998; Tseng et al. 2008c). The chlorophyll $a$ was extracted overnight in $90 \%$ acetone at $4{ }^{\circ} \mathrm{C}$ in the dark (Parsons et al. 1984). Chlorophyll $a$ fluorescence in the acetone extract was measured before and after acidification in a Turner Designs Model 10 Spectrofluorometer in the laboratory at dim light conditions.

Copepod gut pigment contents, evacuation and ingestion rates

Gut pigment contents of copepods were analyzed fluorometrically, following the method of Mackas and Bohrer (1976) with the modifications proposed by Morales et al. (1990). This is an established method to estimate the copepod gut pigment contents that is widely applied in copepod feeding studies around the world (Dagg and Wyman 1983; Atkinson 1994, 1996; Morales et al. 1990). A similar method was used in feeding studies of northern Taiwan (Hwang et al. 1998; Wong et al. 1998) and in the southeastern Taiwan Strait area (Tseng et al. 2008c). The frozen zooplankton samples were thawed and washed with $0.45 \mu \mathrm{m}$ filtered seawater to remove adhering algae or debris before the measurements of the copepods. In the present study, 33 numerically dominant copepod species were selected to measure gut pigments. For each measured 
specimen from one of the three size groups [large (>2 mm), medium (1-2 mm), small $(<1 \mathrm{~mm})], 10-30$ individual copepods were extracted without homogenization in $5 \mathrm{ml}$ of $90 \%$ aqueous acetone in a refrigerator maintained at $4^{\circ} \mathrm{C}$ in the dark (Wong et al. 1998; Hwang et al. 1998; Tseng et al. 2008c) overnight. The extraction solution was centrifuged and the upper clear layer was measured using a Turner Design Model 10 fluorometer in the laboratory, illuminated with dim light. The extract was then acidified with $0.1 \mathrm{ml}$ of $10 \% \mathrm{HCl}$ and measured again. Due to phaeopigment loss during the experiment, all phaeopigment values were multiplied by a factor of 1.51 according to Dagg and Wyman (1983). Gut pigment content was expressed as nanograms chlorophyll $a$ copepod $^{-1}$, obtained from the addition of chlorophyll $a$ and phaeopigment (phaeophorbide expressed as chlorophyll $a$ equivalent) concentrations in the guts.

The gut evacuation rate of each copepod size group was measured from samples collected at the SEATS station. Copepods used for gut evacuation rate measurements were sampled from surface waters, and then transferred to a maintenance tank with $0.45 \mu \mathrm{m}$ filtered seawater after rinsing them with filtered seawater in order to remove algae that adhered to the copepod cuticles. Modest aeration was provided to keep copepods alive during the measure of evacuation rate dynamics. Thereafter, copepod sub-samples were retrieved at $0,1,2,3,5,7,10,15,20,25,30,40$, $50,60,80$ and $100 \mathrm{~min}$ from the start to the end of the study period. Sub-samples were frozen in liquid nitrogen immediately and stored in a dark refrigerator. In the laboratory, chlorophyll $a$ was measured in situ (in the gut) as described above. The evacuation rate was calculated from decreased levels of chlorophyll $a$ in the gut content. The equation employed is as follows:

$G_{\mathrm{t}}=G_{0} \mathrm{e}^{-k t}$

where $G_{\mathrm{t}}$ is the value of gut content at a given time, $G_{0}$ is the value of gut content of the first sample $(0 \mathrm{~min})$ and $k$ is the constant value of evacuation rate.

The ingestion rate was calculated as:

$I=k G$

where $I$ is the ingestion rate (ng chlorophyll $a$ cope$\left.\operatorname{pod}^{-1} \mathrm{~h}^{-1}\right), k$ is the constant value of gut evacuation rate as provided above. And $G$ is the gut pigment content (ng chlorophyll $a$ copepod $^{-1}$ ).

The clearance rate of chlorophyll $a$ per individual was calculated as follows:

$F=I / C$

where $F$ is the clearance rate ( $\mathrm{ml}$ copepod ${ }^{-1} \mathrm{~h}^{-1}$ ), and $\mathrm{C}$ is the in situ chlorophyll $a$ concentration (ng Chl $a \mathrm{ml}^{-1}$ ) in surface waters.

\section{Results}

Hydrological structure and CTD profiles

Monthly-averaged information derived from the National Oceanic and Atmospheric Administration (NOAA) and the Sea-viewing Wide Field-of-view Sensor (SeaWiFS) recordings for sea surface temperature and seawater chlorophyll $a$ values for September 1999 are shown in Fig. 2 . The image for sea surface temperatures (Fig. 2a) shows the region of the northern SCS (rectangle in Fig. 2a, b) with a relatively high temperature above $28^{\circ} \mathrm{C}$. Sea surface concentration of chlorophyll $a$ (Fig. 2b) shows the highest regional distribution along the coast of the mainland of China, especially in the estuary of Yangtze River, reaching levels above $10.0 \mathrm{mg} \mathrm{m}^{-3}$. The chlorophyll $a$ concentration of the northern SCS shows lower values about $0.5 \mathrm{mg} \mathrm{m}^{-3}$. From satellite images it can be concluded that surface waters toward the northern SCS represent high temperature and low chlorophyll $a$ concentrations during the sampling period.

Information about surface seawater temperature, salinity and chlorophyll $a$ concentration at each sampling station are provided in Fig. 3. Surface seawater $(0-5 \mathrm{~m})$ temperatures at six stations were ranging from 28.2 to $28.6^{\circ} \mathrm{C}$ (averaged, $28.4 \pm 0.1^{\circ} \mathrm{C}$ ), whereas surface seawater salinities varied from 33.1 to $33.6 \%$ (averaged $33.3 \pm 0.2 \%$ ). The $\mathrm{Chl}$ $a$ concentration of surface seawater for most stations was low, ranging from 0.018 to $0.031 \mathrm{ng} \mathrm{m}^{-1}$ (averaged $0.026 \pm 0.005 \mathrm{ng} \mathrm{ml}^{-1}$ ).

Gut evacuation rate $(K)$

The gut evacuation rates were measured separately for all three copepod size categories collected at the SEATS station. The estimated parameter values of $K$ were 0.022 , 0.028 and 0.031 , for small, medium and large sized copepods, respectively (Fig. 4).

Copepod gut contents, ingestion and clearance rates

Gut pigment contents of 33 copepod species was estimated by the gut fluorescence method. The gut pigment content of copepods varied greatly among species and stations. The species-specific average gut pigment content, ingestion rates and clearance rates of large-, medium- and small-size fractions are shown in Fig. 5. In the large-size group, the highest gut pigment content, ingestion and clearance rates were recorded in Scolecithrix danae, the values were respectively 7.07 (ng Chl $a$ individual $^{-1}$ ), 13.15 (ng Chl $a$ cope$\left.\operatorname{pod}^{-1} \mathrm{~h}^{-1}\right)$ and $438.33\left(\mathrm{ml}\right.$ copepod $\left.{ }^{-1} \mathrm{~h}^{-1}\right)$. And the lowest record was for Undinula vulgaris with values of 0.61 (ng $\mathrm{Chl}$ $a$ individual $^{-1}$ ), 1.13 (ng Chl $a$ copepod $^{-1} \mathrm{~h}^{-1}$ ) and 40.36 
Fig. 2 Monthly-averaged information derived from NOAA for sea surface temperature (a) and SeaWiFS chlorophyll $a$ (b) of September 1999
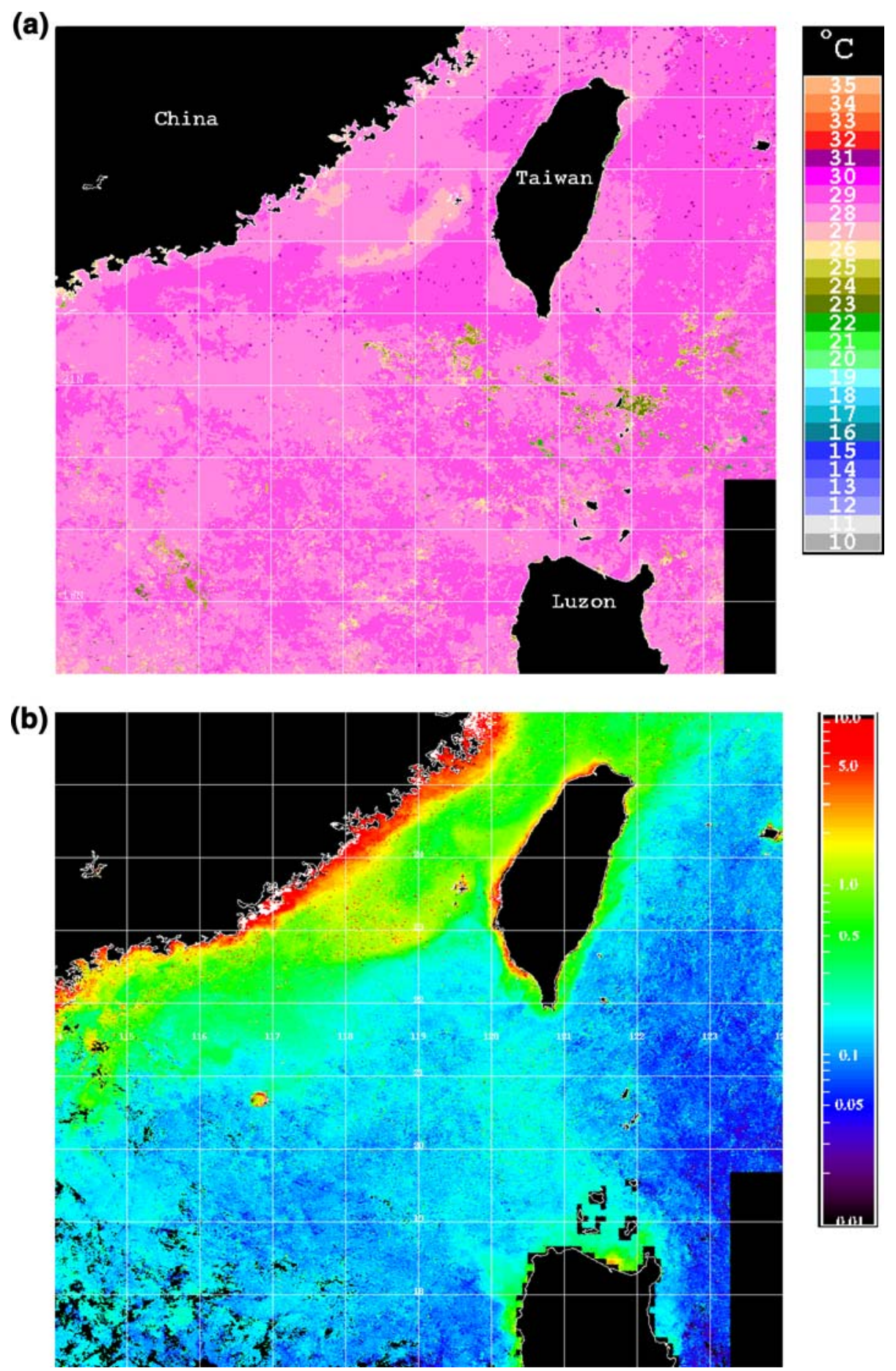

( $\mathrm{ml}$ copepod $^{-1} \mathrm{~h}^{-1}$ ) for gut content, ingestion rate and clearance rate, respectively (Fig. 5a). The calanoid Cosmocalanus darwini recorded the highest gut content, ingestion and clearance rates in the middle size group. The values were 2.45 (ng Chl $a$ individual $^{-1}$ ), 3.97 (ng Chl $a$ cope$\operatorname{pod}^{-1} \mathrm{~h}^{-1}$ ) and $132.33\left(\mathrm{ml}\right.$ copepod ${ }^{-1} \mathrm{~h}^{-1}$ ) for gut content, ingestion and clearance rate, respectively. The lowest records were for Temora discaudata with 0.16 (ng Chl a individual $^{-1}$ ), 0.26 (ng Chl $a$ copepod $^{-1} \mathrm{~h}^{-1}$ ), and 10.40 ( $\mathrm{ml} \mathrm{copepod}{ }^{-1} \mathrm{~h}^{-1}$ ) for gut content, ingestion and clearance rate, respectively (Fig. 5b). Among the small size copepod, the gut contents of most copepods showed values lower than $1 \mathrm{ng}$ Chl $a$ individual $^{-1}$. The highest gut content and ingestion rate for the small-size group was for Calocalanus pavo with values of 1.14 (ng Chl $a$ individual $^{-1}$ ) and 1.50 (ng Chl $a$ copepod $^{-1} \mathrm{~h}^{-1}$ ). The highest clearance rate for 

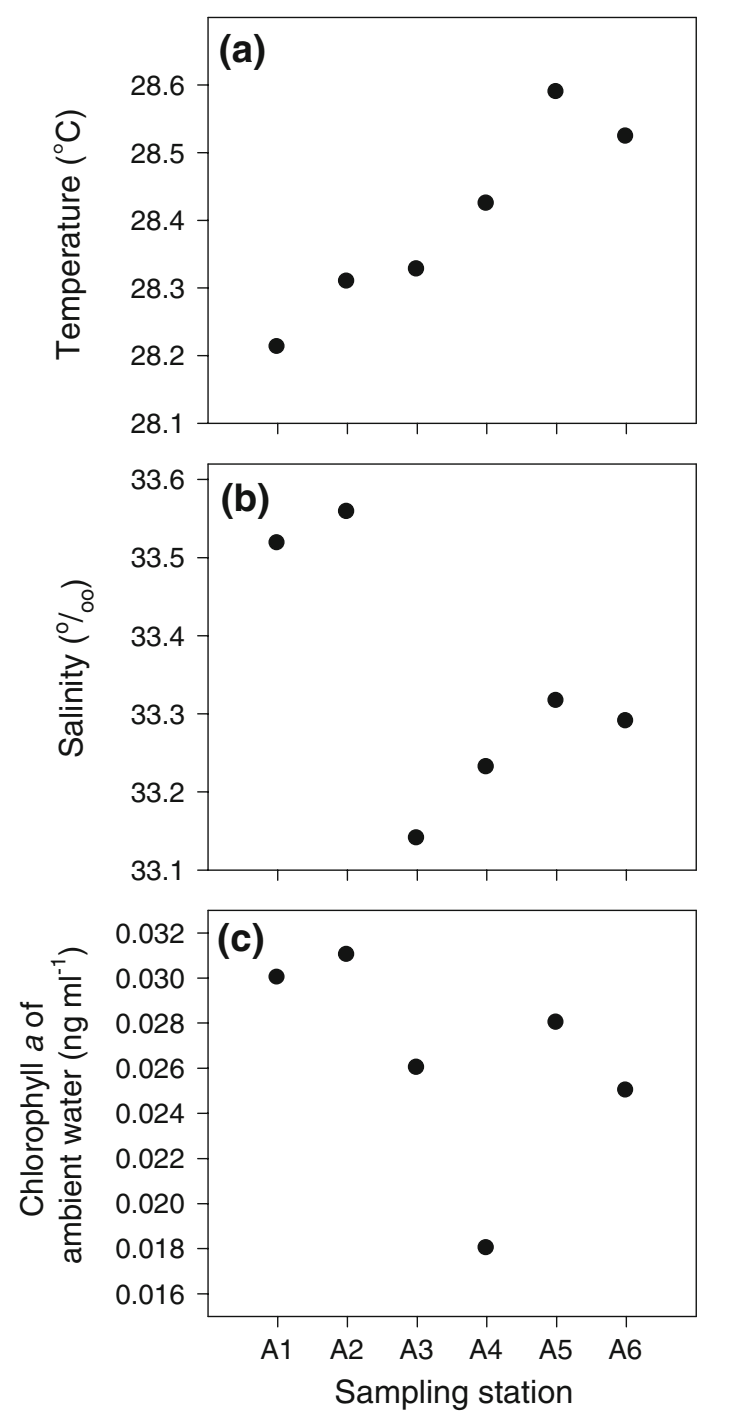

Fig. 3 Hydrologic variation for surface seawater of temperature $\left({ }^{\circ} \mathrm{C}\right)$ (a), salinity (PSU) (b) and Chlorophyll $a\left(\mathrm{ng} \mathrm{ml}^{-1}\right)(\mathbf{c})$ of the six sampling stations

small-size copepods was for Acrocalanus monachus with a value of $66.11\left(\mathrm{ml}\right.$ copepod $\left.^{-1} \mathrm{~h}^{-1}\right)$. The lowest record for gut content, ingestion and clearance rates in small size copepods was for Mecynocera clausi with values of 0.07 (ng Chl $a$ individual $\left.^{-1}\right), 0.09$ (ng Chl $a$ copepod $^{-1} \mathrm{~h}^{-1}$ ) and $5.00\left(\mathrm{ml} \mathrm{copepod}^{-1} \mathrm{~h}^{-1}\right)$, respectively (Fig. 5c).

Totally, we measured 80 samples (including 1,468 individuals), the results showed that large-size $(>2 \mathrm{~mm})$ copepods recorded significantly higher gut pigment contents $\left(1.88 \pm 1.89 \mathrm{ng} \mathrm{Chl} a\right.$ individual $\left.^{-1}\right)$ than mediumsize $(1-2 \mathrm{~mm})\left(0.87 \pm 0.57 \mathrm{ng} \mathrm{Chl} a\right.$ individual $\left.^{-1}\right)$ (one way ANOVA, $P=0.025)$ and small size $(<1 \mathrm{~mm})$ species $\left(0.51 \pm 0.94 \mathrm{ng} \mathrm{Chl} a\right.$ individual $\left.^{-1}\right)$ (one way ANOVA, $P<0.001$ ) (Fig. 6a). The amount of gut pigment in the medium and in small size fractions did not differ significantly ( $P=0.401$, one way ANOVA) (Fig. 6a). As for the

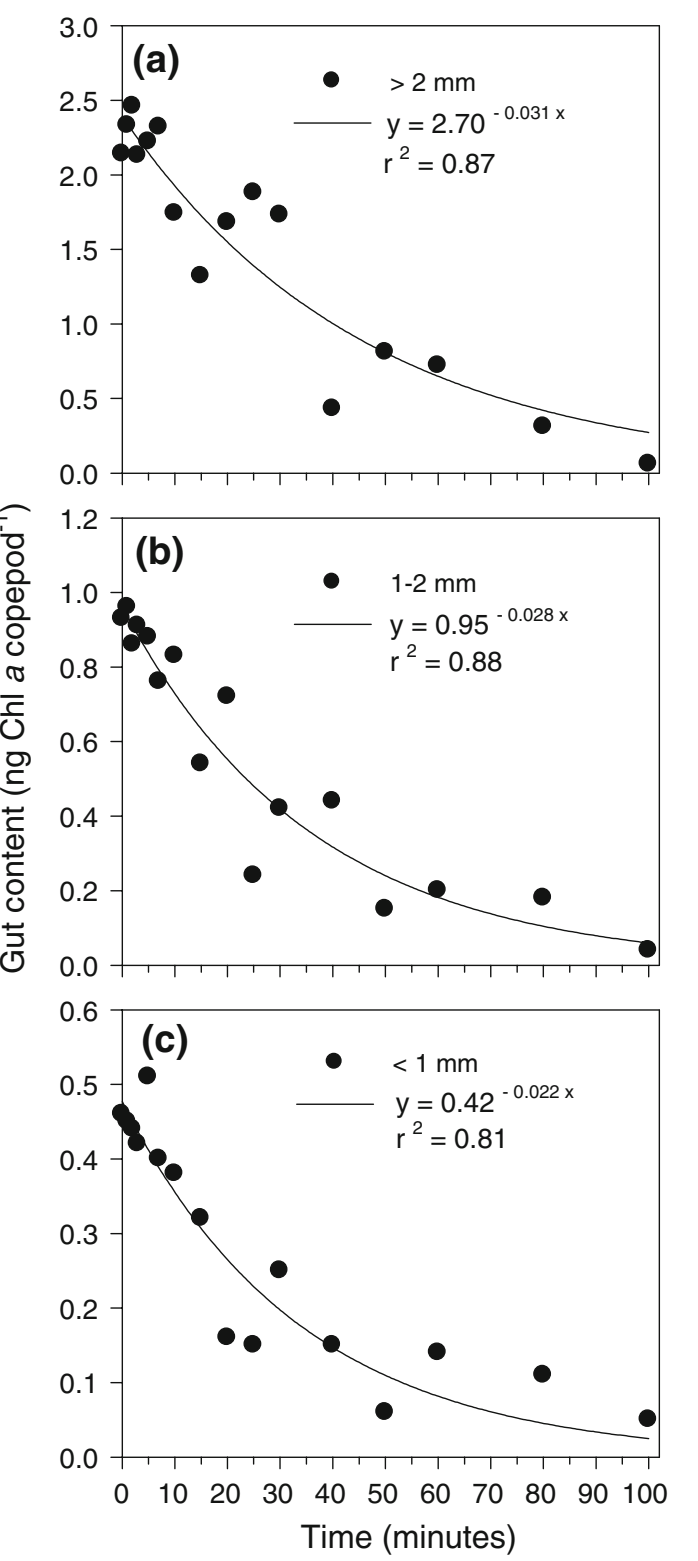

Fig. 4 Evacuation rates of three copepod body size groups. a $>2 \mathrm{~mm}, \mathbf{b} 1-2 \mathrm{~mm}$ and $\mathbf{c}<1 \mathrm{~mm}$

ingestion rates, large-size copepods showed significantly higher rates $\left(3.50 \pm 3.52 \mathrm{ng} \mathrm{Chl} a\right.$ copepod $\left.^{-1} \mathrm{~h}^{-1}\right)$ than medium-size copepods $(1.39 \pm 0.93 \mathrm{ng} \mathrm{Chl} a$ cope$\operatorname{pod}^{-1} \mathrm{~h}^{-1}$ ) (one-way ANOVA, $P=0.001$ ) and small-size species $\left(0.50 \pm 0.35 \mathrm{ng}\right.$ Chl $a$ copepod $\left.^{-1} \mathrm{~h}^{-1}\right)$ (one-way ANOVA, $P<0.001$ ) (Fig. 6b). The ingestion rates in the medium- and small-size fractions did not differ significantly ( $P=0.09$, one-way ANOVA) (Fig. 6b). Large-size copepods showed significantly higher clearance rates $\left(125.22 \pm 113.02 \mathrm{ml} \mathrm{copepod}^{-1} \mathrm{~h}^{-1}\right)$ than the mediumsize group $\left(51.45 \pm 30.23 \mathrm{ml}\right.$ copepod $^{-1} \mathrm{~h}^{-1}$ ) (one-way ANOVA, $P<0.001)$ and small-size species $(20.06 \pm$ $14.04 \mathrm{ml} \mathrm{copepod}^{-1} \mathrm{~h}^{-1}$ ) (one-way ANOVA, $P<0.001$ ) 

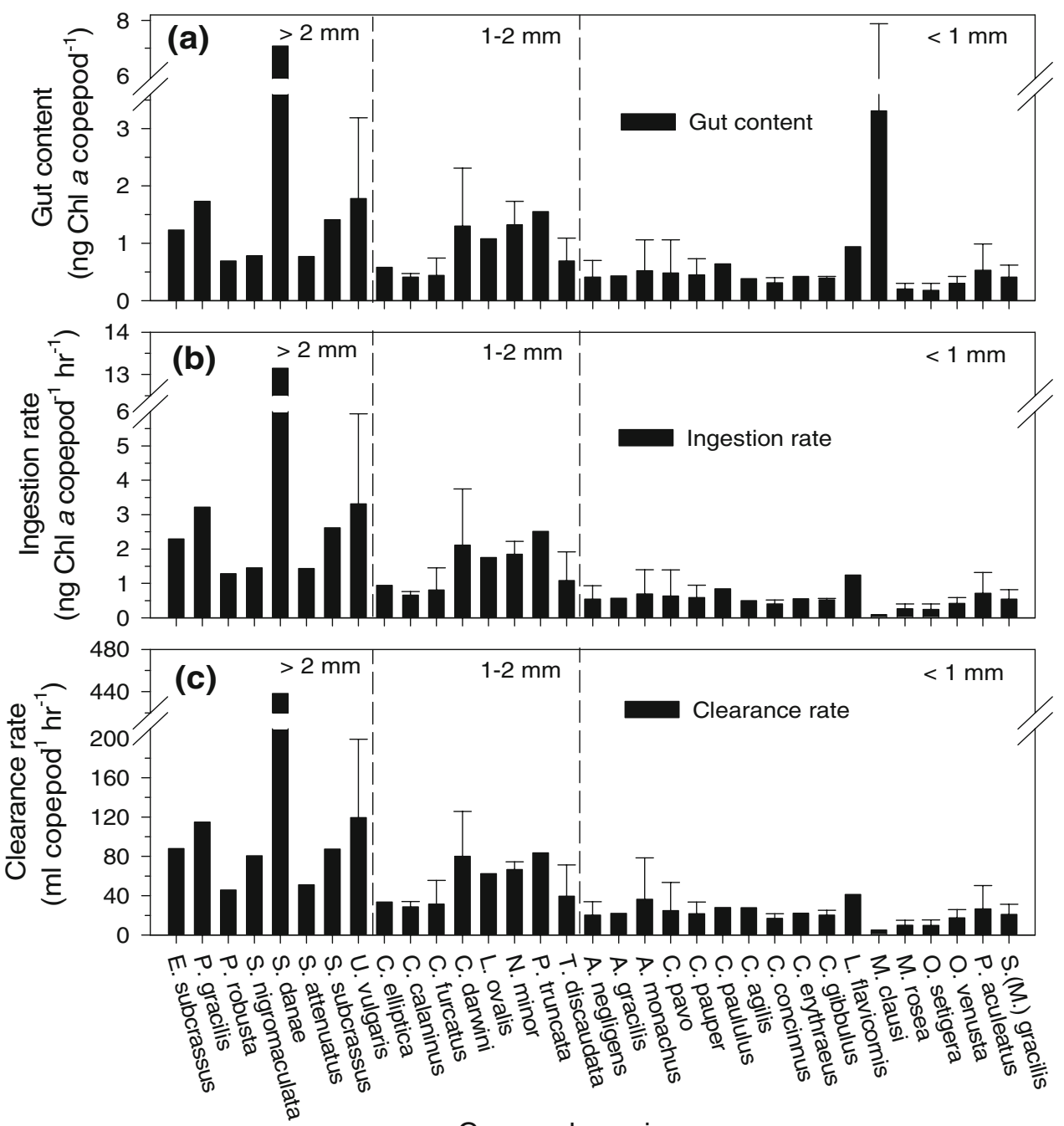

Copepod species

Fig. 5 Species-specific average value (+SD) of gut chlorophyll $a$ content (a), ingestion rates (b) and clearance rates (c). E. subcrassus: Eucalanus subcrassus, $P$. gracilis: Pleuromamma gracilis, $P$. robusta: Pleuromamma robusta, $S$. nigromaculata: Sapphirina nigromaculata, S. danae: Scolecithrix danae, S. attenuatus: Subeucalanus attenuatus, S. subcrassus: Subeucalanus subcrassus, U. vulgaris: Undinula vulgaris, C. elliptica: Calanopia elliptica, C. calaninus: Centropages calaninus, C. furcatus: Centropages furcatus, C. darwini: Cosmocalanus darwini, L. ovalis: Lucicutia ovalis, N. minor: Nannocalanus minor, P. truncata: Paracandacia truncata, T. discaudata: Temora

(Fig. 6a). The clearance rates in the medium- and smallsize fractions did not significantly differ $(P=0.058$, oneway ANOVA) (Fig. 6c).

The amount of gut pigment contents in 33 copepod species (including 70 samples and 1,290 individuals) showed a decreasing trend with increasing water temperature (Fig. 7a). The gut pigment content values showed a significantly negative correlation with temperature (Pearson correlation $n=70, r=-0.62, P=0.014$; Fig. 7a). This holds for large-size copepods (Pearson correlation $n=11$, $r=-0.87, P=0.019$; Fig. 7a) and medium-size copepods (Pearson correlation $n=19, \quad r=-0.89, \quad P=0.012$; discaudata, A. negligens: Acartia negligens, A. gracilis: Acrocalanus gracilis, A. monachus: Acrocalanus monachus, C. pavo: Calocalanus pavo, C. pauper: Canthocalanus pauper, C. paululus: Clausocalanus paululus, C. agilis: Corycaeus agilis, C. concinnus: Corycaeus concinnus, C. erythraeus: Corycaeus erythraeus, C. gibbulus: Corycaeus gibbulus, L. flavicornis: Lucicutia flavicornis, M. clausi: Mecynocera clausi, M. rosea: Microsetella rosea, O. setigera: Oithona setigera, O. venusta: Oncaea venusta, P. aculeatus: Paracalanus aculeatus and S.(M.) gracilis: Setella (Macrosetella) gracilis

Fig. 7a). However, gut pigment content showed a significantly positive correlation with the Chl $a$ concentration in ambient waters (Pearson correlation $n=70, r=0.62$, $P=0.043$; Fig. 7b).

\section{Discussion}

Our results might have been affected by size and morphology of potential algal food. Algal cells that are too large or too small (Brendelberger 1991) can not be ingested by zooplankton. Apart from the actual cell size, has prey 

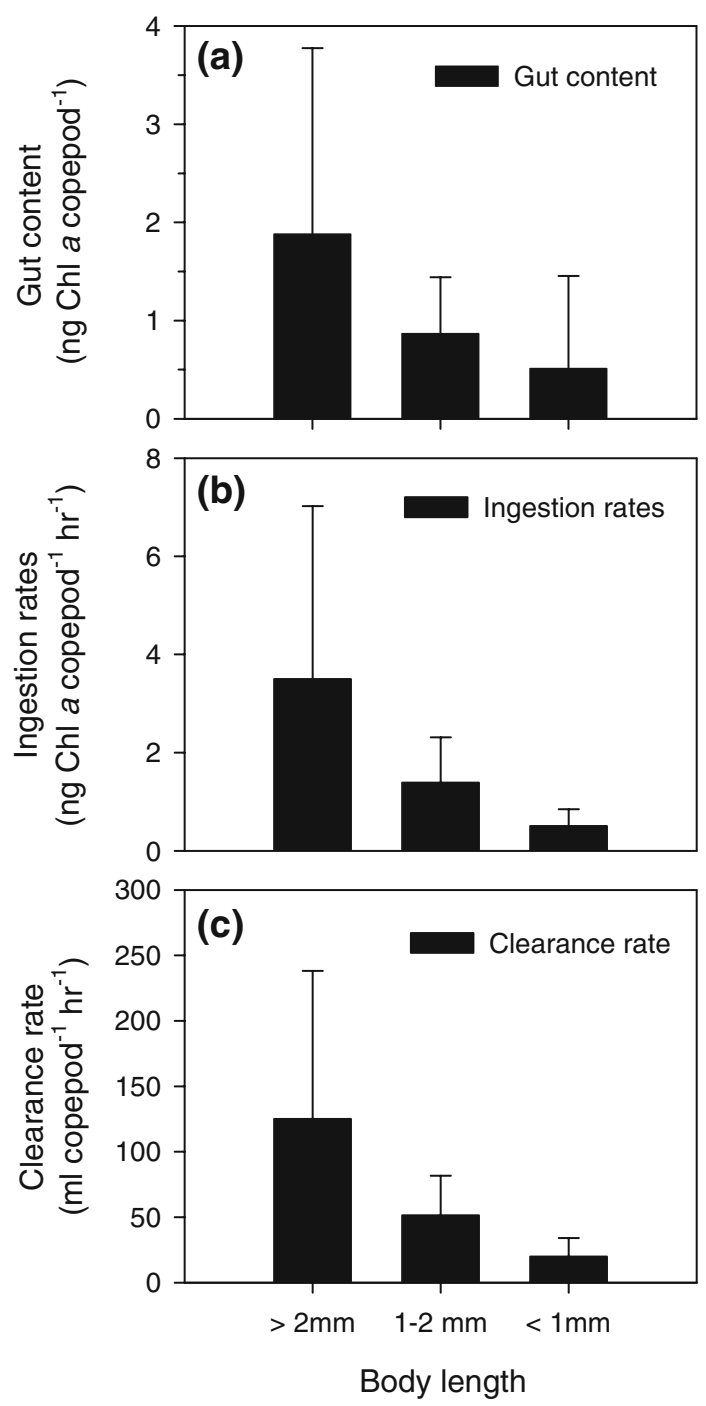

Fig. 6 Average values ( $\pm \mathrm{SD}$ ) of a gut chlorophyll (Chl) a content, b ingestion rate, and c clearance rate for large-sized $(>2 \mathrm{~mm})$, medium- $(1-2 \mathrm{~mm})$ and small- $(<1 \mathrm{~mm})$ fractions of copepods in the tropical South China Sea

hardness a major impact on the ability of copepods to ingest food particles (DeMott and Tessier 2002). The architecture and material properties of diatom shells may in turn provide effective mechanical protection (Hamm et al. 2003), or gelatinous sheaths that prevent digestion by zooplankter. In addition may be different zooplankter have specific preferences for food particle size. This is generally determined by the gape size of the oral appendages. The lower end of food particle size is set by the mesh size in the filtering apparatus (DeMott and Tessier 2002).

Copepod gut contents, ingestion, clearance and rates

The gut pigment contents, ingestion and clearance rates of copepods varied among species and stations of the present study. Gut evacuation, ingestion and clearance rates recorded in the present study were within the range of those reported from copepods collected from other oceans worldwide (Morales et al. 1990), the studies of the northern Taiwan coastal area (Hwang et al. 1998; Wong et al. 1998) and the southeastern Taiwan Strait (Tseng et al. 2008c).

In the present study large-size copepods show significantly higher values of gut pigment contents, ingestion rate and clearance rate than medium-size and small-size species. The amount of gut pigments in the medium and small size fractions does not differ significantly. Gut pigment contents tended to increase with increasing copepod size in several other studies (Tseng et al. 2008b) as well as with phytoplankton concentration and cell size $(>10 \mu \mathrm{m})$ (Hansen et al. 1997). As other marine zooplankton, copepods graze more food with increasing body size (Hansen et al. 1997). The present results are similar to several previous feeding studies (Hwang et al. 1998; Wong et al. 1998; Tseng et al. 2008c). Larger copepods may have a bigger gut volume and higher energy expenditure required for metabolism and, hence, the value of chlorophyll $a$ in the gut contents increases with increasing body size (Tseng et al. 2008b).

In our study, the amount of gut pigment contents showed a decreasing trend (our Fig. 7a), particularly for large- and medium-size copepods, with increasing water temperature. This has been elaborated before by Dam and Peterson (1988). Gut pigment content showed a significantly positive correlation with the $\mathrm{Chl} a$ concentration in ambient waters of the present study. Similarly, increasing gut pigment content and food concentration (Ellis and Small 1989), or gut pigment content with phytoplankton concentration and cell size $(>10 \mu \mathrm{m})$ is shown in other studies (Froneman et al. 2000).

The present investigation confirms the results of studies from waters of the southeastern Taiwan Strait where a significant correlation was recorded between the ambient chlorophyll $a$ concentration and copepod gut contents (Tseng et al. 2008c). The authors interpreted the variability in grazing impact during the study period mainly as a result of differences in both copepod abundances and copepod feeding rates, similar to findings of Tan et al. (2004). The feeding rhythm is an important factor in copepod feeding behavior. Lee (1999) found that maximum copepod feeding occurred at night for copepods, in both surface and depths samples. Accordingly, were gut pigment contents shown to be maximal during nighttime and minimal during daytime (Saito and Taguchi 1996).

Gut evacuation rates

The rank of gut evacuation rates for each size groups are similar as in the southeastern Taiwan Strait area (Tseng et al. 2008c) and depend on body size. Tan et al. (2004) 
Fig. 7 Correlation between copepod gut content $(\mathrm{Chl} a)$ with Sea water temperature (a) and ambient chlorophyll $a$ concentration (b) at six stations in the northern South China Sea
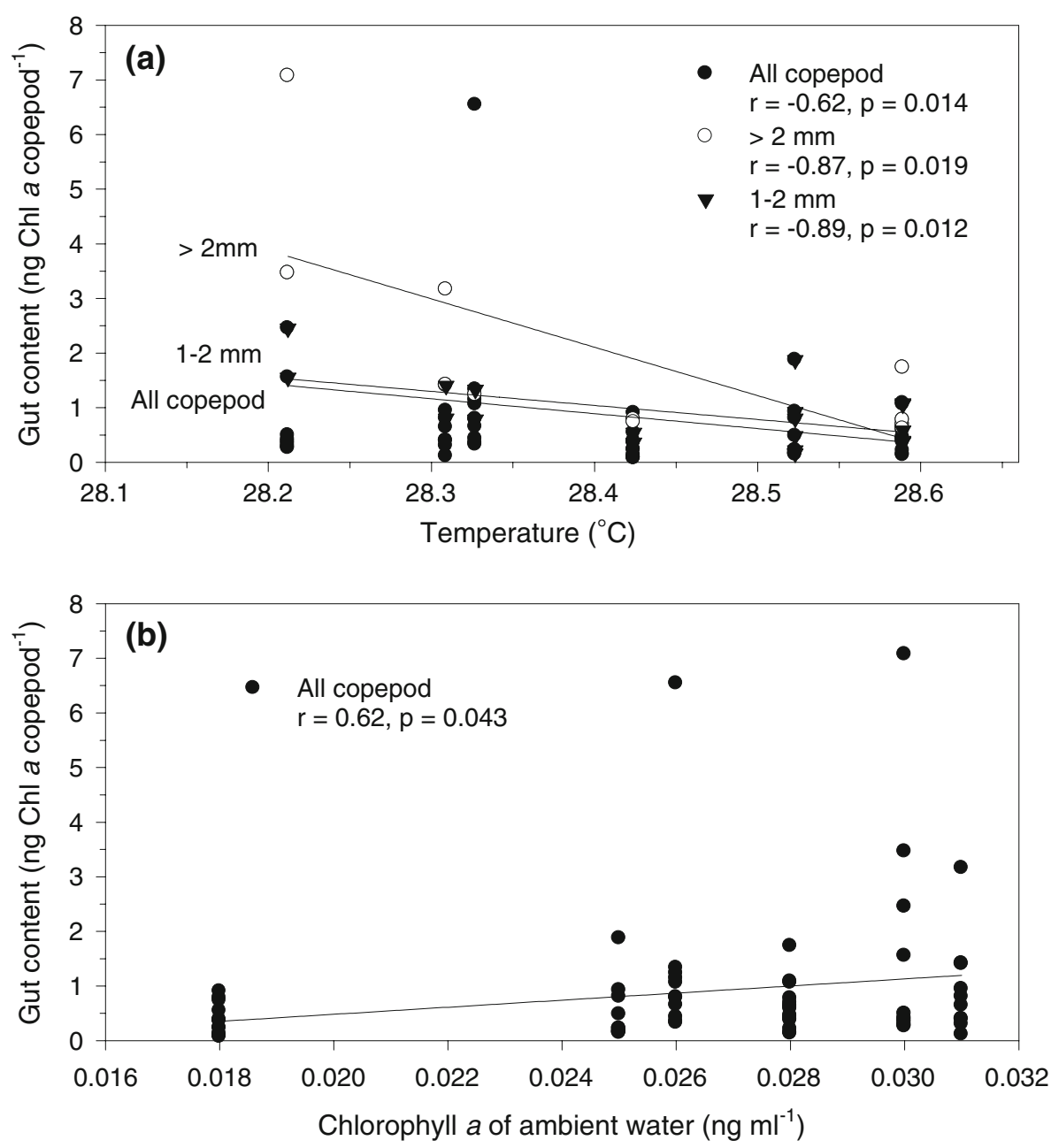

obtained slightly higher evacuation rates than the present study (averaged $0.027 \pm 0.005$ ) from the northwestern SCS close to the area of the Pearl River estuary, compared to the study in the southeastern Taiwan Strait of Tseng et al. (2008c) where evacuation rates were lower (averaged $0.015 \pm 0.002)$.

In the present study we did not calculate the feeding impact of copepods on phytoplankton due to the fact that copepod compositions were different in two sampling tows. Some copepod species where the gut contents were analyzed, could not be identified in the second tow. From the experience of the present study we suggest to use a Bongo net for sampling that would decrease the spatiotemporal effects of asynchronous sampling.

The feeding impact values of the present and previous studies north to the present sampling area showed a high variation. In northern Taiwan, Wong et al. (1998) reported feeding impacts of calanoid copepods on phytoplankton that ranged from 0.05 to $11 \%$ in coastal waters near a nuclear power plant. Tseng et al. (2008c) reported feeding impact values in the southeastern Taiwan Strait that ranged between 0.001 and $0.211 \%$. In contrast, the higher records in the Pearl River estuary ranged between $<0.3$ and $75 \%$, suggesting a lower feeding impact on the phytoplankton (Tan et al. 2004). Morales et al. (1991) estimated that copepods consumed $<1 \%$ of the phytoplankton standing stock, and lower records of Peterson et al. (1990) reported that neritic copepods grazed about $1 \%$ and midshelf copepods about $5 \%$ of the overall phytoplankton per day. Since the present study site is close to that in the study of Tseng et al. (2008c) we expect the grazing impact of copepods on the phytoplankton in the north SCS to be similar to the southeastern Taiwan Strait (Tseng et al. 2008 c). Both studies were performed in tropical seas at similar warm water temperature with lower chlorophyll $a$ concentrations. Comparing the present results to the study by Tseng et al. (2008c), we confirm the same trend for the gut contents in three sized copepod groups which show significantly highest differences in large copepods than middle and small size copepods. In addition was the gut content of copepods significantly positive correlated with the chlorophyll $a$ concentration of the ambient seawater. 


\section{Conclusions}

Grazing budgets are likely affected by sources of error associated with the methods employed. Large mesh sizes for example will allow smaller sized copepods to escape. A small size group also includes copepodids and nauplii of larger growing species that are predominantly herbivorous, even when the adults are predatory. Grazing budgets commonly not consider postembryonic stages (nauplii and copepodids) which resulted in an underestimation of overall grazing rates by copepod standing stocks.

The measurement of copepod feeding impact on phytoplankton should consider sampling timing, which correlates with the diurnal migration behavior of copepods. Copepod guts might not be fully expanded since copepods are not feeding continuously, and sampling time was possibly not matched with feeding time. It is difficult to ascertain to what extent the food media used in incubation experiments simulate a natural situation. Hence, incubation studies would not provide the true relationship between food availability and feeding by copepods, unless the gut contents are inspected. Copepod feeding is dynamic and commonly shows a remarkable variability. This may explain why some smallersize copepods in the present study have relatively more gut content than larger sized copepods.

Pure herbivory appears to be the exception rather than the rule in copepod feeding. The type of food seems not only to be related to taxa, but also to gender, ontogeny, physiological state as well as to environmental parameters and the type and quantity of potential diets available in the respective environments.

Given a heterogeneous assemblage that can be of dietary use, the question whether copepods feed selectively or nonselectively is not resolved for most species yet due to difficulties in identifying their diets (Lapesa et al. 2004).

Although considerable progress has been made in defining the effects of qualitative and quantitative food limitation, several questions are still open, especially with respect to essential and substitutable nutritional resources. Food quality effects on herbivorous zooplankton were studied by Urabe and Sterner (2001).

Acknowledgments We acknowledge the captain and crew of Ocean Research Vessel III for assistance and logistical support during the cruises. We acknowledge the technical help of C.Z. Chen and S.C. Wong during the sampling campaigns. This research was supported by grants (NSC 89-2611-M-019-034-OP1; NSC 96-2611-M-019-006 and NSC 97-2611-M-019-004) from the National Science Council, Taiwan to J.S. Hwang.

\section{References}

Atkinson A (1994) Diets and feeding selectivity among the epipelagic copepod community near South Georgia in summer. Polar Biol $14: 551-560$
Atkinson A (1996) Subantarctic copepods in an oceanic, low chlorophyll environment: ciliate predation, food selectivity and impact on prey populations. Mar Ecol Prog Ser 130:85-96

Bouvy M, Ba N, Ka S, Sane S, Pagano M, Arfi R (2006) Phytoplankton community structure and species assemblage succession in a shallow tropical lake (Lake Guiers, Senegal). Aquat Microb Ecol 45(2):147-161

Brendelberger H (1991) Filter mesh-size of cladocerans predicts retention efficiency for bacteria. Limnol Oceanogr 36:884-894

Ceballos S, Alvarez-Marques F (2006) Reproductive activity and physiological status of the calanoid copepods Calanus helgolandicus and Calanoides carinatus under food-limiting conditions. J Exp Mar Biol Ecol 339:189-203

Chen QC, Zhang SZ (1965) The planktonic copepods of the Yellow Sea and the East China Sea. I. Calanoida. (In Chinese, with English abstract). Stud Mar Sin 7:20-133

Chen QC, Zhang SZ, Zhu CS (1974) On planktonic copepods of the Yellow Sea and the East China Sea. II. Cyclopoida and Harpacticoida (In Chinese, with English abstract). Stud Mar Sin 9:27-100

Cotonnec G, Brunet C, Sautour B, Thoumelin G (2001) Nutritive value and selection of food particles by copepods during a spring bloom of Phaeocystis sp. in the English Channel, as determined by pigment and fatty acid analyses. J Plankton Res 23:693-703

Dagg MJ, Wyman KD (1983) Natural ingestion rates of the copepods Neocalanus plumchrus and $N$. cristatus calculated from gut content. Mar Ecol Prog Ser 13:37-46

Dahms H-U, Qian P-Y (2005) Exposure of biofilms to meiofaunal copepods affects the larval settlement of Hydroides elegans (Polychaeta). Mar Ecol Prog Ser 297:203-214

Dahms HU, Qian PY (2006) Kin-recognition during intraspecific predation of Harpacticus sp. (Copepoda, Harpacticoida)? Zool Stud 45(3):395-403

Dahms HU, Harder T, Qian P-Y (2006) Selective attraction and reproductive performance of a harpacticoid copepod in a response to biofilms. J Exp Mar Biol Ecol 341:228-238

Dam HG, Peterson WT (1988) The effect of temperature on the gut clearance rate constant of planktonic copepods. J Exp Mar Biol Ecol 123:1-14

DeMott WR, Tessier AJ (2002) Stoichiometric constraints vs. algal defenses: testing mechanisms of zooplankton food limitation. Ecology 83:3426-3433

Ellis SG, Small LF (1989) Comparison of gut-evacuation rates of feeding and non-feeding Calanus marshallae. Mar Biol 103:175-181

Froneman PW, Pakhomov EA, Perissinotto R, McQuaid CD (2000) Zooplankton structure and grazing in the Atlantic sector of the Southern Ocean in late austral summer. Part 2. Biochemical zonation 1993. Deep Sea Res I 47:1687-1702

Go YB, Oh BC, Terazaki M (1998) Feeding behavior of the poecilostomatoid copepods Oncaea sp. on chaetognaths. J Mar Syst 15:475-482

Gowen RJ, McCullough G, Kleppel GS, Houchin L, Elliott P (1999) Are copepods important grazers of the spring phytoplankton bloom in the western Irish Sea? J Plankton Res 21:465-483

Hamm CE, Merkel R, Springer O, Jurkojc P, Maier C, Prechtel K, Smetacek V (2003) Architecture and material properties of diatom shells provide effective mechanical protection. Nature 421:841-843

Hansen PJ, Bjørnsen PK, Hansen BW (1997) Zooplankton grazing and growth: scaling within the $2-2000-\mu \mathrm{m}$ body size range. Limnol Oceanogr 42:687-704

Head RN, Harris RP, Bonnet D, Irigoien X (1999) A comparative study of size fractionated mesozooplankton biomass and grazing in the North East Atlantic. J Plankton Res 21:2282-2308

Hwang JS, Chen QC, Wong CK (1998) Taxonomic composition and grazing rate of calanoid copepods in coastal waters of northern Taiwan. Crustaceana 71:378-389 
Irigoien X, Harris RP, Verheye HM, Joly P, Runge J, Starr M, Pond D, Campbell R, Shreeve R, Ward P, Smith AN, Dam HG, Peterson W, Davidson R (2002) Copepod hatching success in marine ecosystems with high diatom concentrations. Nature 419:387-389

Katechakis A, Stibor H (2004) Feeding selectivities of the marine cladocerans Penilia avirostris, Podon intermedius and Evadne nordmanni. Mar Biol 145:529-539

Kleppel GS (1992) Environmental regulation of feeding and egg production by Acartia tonsa off southern California. Mar Biol 112:57-65

Kleppel GS, Burkart CA, Carter K, Tomas C (1996) Diets of calanoid copepods on the west Florida continental shelf: relationships between food concentration, food composition and feeding activity. Mar Biol 127:209-217

Lapesa S, Snell TW, Fields DM, Serra M (2004) Selective feeding of Arctodiaptomus salinus (Copepoda, Calanoida) on co-occurring sibling rotifer species. Freshw Biol 49:1053-1061

Lee CR (1999) Feeding impact of copepods (Calanoida) in the nearshore waters of southwestern Taiwan. Master's thesis. Institute of Marine Biology, National Taiwan Ocean University, Keelung, 57pp (in Chinese)

Lo WT, Hwang JS, Chen QC (2004) Spatial variations of copepods in the surface water of Southeastern Taiwan Strait. Zool Stud 43:218-228

Mackas D, Bohrer R (1976) Fluorescence analysis of zooplankton gut contents and an investigation of diel feeding patterns. J Exp Mar Biol Ecol 25:77-85

Meyer B, Irgoien X, Graeve M, Head RN, Harris LR (2002) Feeding rates and selectivity among nauplii, copepodites and adult females of Calanus finmarchicus and Calanus helgolandicus. Helgol Mar Res 56:169-176

Meyer-Harms B, von Bodungen B (1997) Taxon-specific ingestion rates of natural phytoplankton by calanoid copepods in an estuarine environment (Pomeranian Bight, Baltic Sea) determined by cell counts and HPLC analyses of marker pigments. Mar Ecol Prog Ser 153:187-190

Møller EF (2005) Sloppy feeding in marine copepods: prey-sizedependent production of dissolved organic carbon. J Plankton Res 27:27-35

Morales CE, Bautista B, Harris RP (1990) Estimates of ingestion in copepod assemblages gut fluorescence in relation to body size. In: Barnes M, Gibson RN (eds) Trophic relationships in the marine environment. Aberdeen University press, Aberdeen, pp $565-577$

Morales CE, Bedo A, Harris RP, Tranter PRG (1991) Grazing of copepod assemblages in the north-east Atlantic: the importance of the small size fraction. J Plankton Res 13:455-472

Nishida S, Ohtsuka S (1996) Specialized feeding mechanism in the pelagic copepod genus Heterorhabdus (Calanoida: Heterorhabdidae), with special reference to the mandibular tooth and labral glands. Mar Biol 126:619-632

Parsons TR, Maita Y, Lalli CM (1984) A manual of chemical and biological methods for seawater analysis. Pergamon Press, Oxford, 173pp

Peterson WT, Painting SJ, Hutchings L (1990) Diel variations in gut pigment content, diel vertical migration and estimates of grazing impact for copepods in the southern Benguela upwelling region in October 1987. J Plankton Res 12:259-281

Razouls S, Réau GD, Guillot P, Maison J, Jeandel C (1998) Seasonal abundance of copepod assemblages and grazing pressure in the Kerguelen Island area (Southern Ocean). J. Plankton Res 20:1599-1614

Romam RR, Gauzens AL (1997) Copepod grazing in the equatorial Pacific. Limnol Oceanogr 42:623-634
Saito H, Taguchi S (1996) Diel feeding behavior of neritic copepods during spring and fall blooms in Akkeshi Bay, eastern coast of Hokkaido, Japan. Mar Biol 125:97-107

Schminke HK (2007) Entomology for the copepodologist. J Plankton Res 29:149-162

Schnetzer A, Caron DA (2005) Copepod grazing impact on the trophic structure of the microbial assemblage of the San Pedro Channel, California. J Plankton Res 27:959-972

Schultes S, Verity PG, Bathmann U (2006) Copepod grazing during an iron-induced diatom bloom in the Antarctic Circumpolar Current (EisenEx): I. Feeding patterns and grazing impact on prey populations. J Exp Mar Biol Ecol 338:16-34

Stoecker DK, Capuzzo JM (1990) Predation on protozoa: its importance to zooplankton. J Plankton Res 12:891-908

Strickland JDH, Parsons TR (1972) A practical handbook of seawater analysis, vol 167, 2nd edn. Bulletin of the Fisheries Research Board of Canada, Ottawa, 311pp

Tackx MLM, Herman PJM, Gasparini S, Irgoien X, Billiones R, Daro MH (2003) Selective feeding of Eurytemora affinis (Copepoda, Calanoida) in temperate estuaries: model and field observations. Estuar Coast Shelf Sci 56:305-311

Tan Y, Huang L, Chen Q, Hwang X (2004) Seasonal variation in zooplankton composition and grazing impact on phytoplankton standing stocks in the Pearl River Estuary, China. Continent Shelf Res 24:1949-1968

Tseng LC, Souissi S, Dahms HU, Chen QC, Hwang JS (2008a) Copepod communities related to water masses in the southwest East China Sea. Helgol Mar Res 62:153-165

Tseng LC, Kumar R, Dahms HU, Chen CT, Chen QC, Hwang JS (2008b) Epipelagic mesozooplankton succession and community structure above a marine outfall in the northeastern South China Sea. J Environ Biol 29:275-280

Tseng LC, Kumar R, Dahms HU, Chen QC, Hwang JS (2008c) Copepod gut contents, ingestion rates and feeding impact in relation to their size structure in the southeastern Taiwan Strait. Zool Stud 47:402-416

Turner JT (2002) Zooplankton fecal pellets, marine snow and sinking phytoplankton blooms. Aquat Microb Ecol 27:57-102

Turner JT (2004) The importance of small planktonic copepods and their roles in pelagic marine food webs. Zool Stud 43:255-266

Turner JT, Levinsen H, Nielsen TG, Hansen BW (2001) Zooplankton feeding ecology: grazing on phytoplankton and predation on protozoans by copepod and barnacle nauplii in Disko Bay, West Greenland. Mar Ecol Prog Ser 221:209-219

Urabe J, Sterner RW (2001) Contrasting effects of different types of resource depletion on life history traits in Daphnia. Funct Ecol 15:165-174

Wang R, Fan C (1997) Copepod feeding activities and its contribution to downward vertical flux of carbon in the East China Sea. Oceanol Limnol Sin 28(6):579-587

Wong CK, Hwang JS, Chen QC (1998) Taxonomic composition and grazing impact of calanoid copepods in coastal water near nuclear power plants in northern Taiwan. Zool Stud 37:330-339

Wu CH, Hwang JS, Yang JS (2004) Diets of three copepods (Poecilostomatoida) in the southern Taiwan Strait. Zool Stud 43(2):388-392

Wyckmans M, Chepurnov VA, Vanreusel A, De Troch M (2007) Effects of food diversity on diatom selection by harpacticoid copepods. J Exp Mar Biol Ecol 345:119-128

Zheng Z, Li S, Li SQ, Chen BY (1982) Marine planktonic copepods of China, vol 2 (In Chinese). Shanghai Science and Technology Press, Shanghai 